\title{
Benefits and limits of X-ray micro-computed tomography for visualization of colonization and bioerosion of shelled organisms
}

\author{
Zuzana Heřmanová, Jana Bruthansová, Katarína Holcová, Radek Mikuláš, \\ Martina Kočová Veselská, Tomáš Kočí, Jan Dudák, and Martin Vohník
}

\begin{abstract}
Micro-computed tomography (micro-CT) allows non-invasive imaging of internal structures of various objects. Micro-CT devices (x-ray microscope, CT scanner) utilize $x$-rays to see inside the object and enable its three-dimensional (3D) reconstruction. Here, a large set of shells (>60 specimens) of varying composition and origin were visualized using micro-CT to test its efficiency for investigation of (micro-)borings and other colonization structures. The set covered various materials and structures of marine shells, from the Ordovician to recent, some of them being influenced by diagenetic changes; it comprised internal moulds of invertebrate body fossils preserved in the siliceous nodules, bryozoan colony from marls to clayey limestones, epibiontic interactions of bryozoan colonies and conulariid specimens with apatitic periderm from clay limestones sediments, calcareous shells of platycerid gastropods from organodetritic limestones, microborings in peloidal grainstone, calcitic or calcitic/aragonitic serpulid tube worms, organic-walled lacustrine egg-like bodies, and recent foraminiferas from the Mediterranean. We focused on various structures from minute microborings to macroborings, burrows, and epibionts. Optimal settings of micro-CT devices for different types of shells combined with different types of borings and their fillings, burrows, and epibionts are suggested. Three-dimensional visualization of the surfaces of fossil shelled organisms using surface modelling is proposed. The main benefits of micro-CT include its non-destructive nature (measurements can be repeated, valuable specimens can be preserved for further studies, etc.) and reasonable 3D visualization of inner structures. On the other hand, resolutions of less than $1 \mu \mathrm{m}$ cannot be effectively achieved, and this may limit studies on microborings by bacteria and certain fungi.
\end{abstract}

Zuzana Heřmanová. Department of Palaeontology, National Museum, Cirkusová 1740, 193 00, Prague 9 , Czech Republic, zuzka.hermanova@gmail.com

Jana Bruthansová. Department of Palaeontology, National Museum, Cirkusová 1740, 193 00, Prague 9 , Czech Republic, \& Institute of Geology and Palaeontology, Faculty of Science, Charles University, Albertov 6, 12843 Prague 2, Czech Republic, jana_bruthansova@nm.cz

Katarína Holcová. Institute of Geology and Palaeontology, Faculty of Science, Charles University, Albertov

Heřmanová, Zuzana, Bruthansová, Jana, Holcová, Katarína, Mikuláš, Radek, Kočová Veselská, Martina, Kočí, Tomáš, Dudák, Jan, and Vohník, Martin. 2020. Benefits and limits of x-ray micro-computed tomography for visualization of colonization and bioerosion of shelled organism. Palaeontologia Electronica, 23(2):a23. https://doi.org/10.26879/1048

palaeo-electronica.org/content/2020/3032-micro-ct-bioerosion

Copyright: May 2020 Paleontological Society.

This is an open access article distributed under the terms of Attribution-NonCommercial-ShareAlike 4.0 International (CC BY-NC-SA 4.0 ), which permits users to copy and redistribute the material in any medium or format, provided it is not used for commercial purposes and the original author and source are credited, with indications if any changes are made.

creativecommons.org/licenses/by-nc-sa/4.0/ 
6, 12843 Prague 2, Czech Republic, holcova@natur.cuni.cz Radek Mikuláš. Institute of Geology, Czech Academy of Sciences, Rozvojová 269, CZ-165 02 Prague 6, Czech Republic, mikulas@gli.cas.cz

Martina Kočová Veselská. Institute of Geology, Czech Academy of Sciences, Rozvojová 269, CZ-165 02 Prague 6, Czech Republic \& Institute of Geology and Palaeontology, Faculty of Science, Charles University, Albertov 6, 12843 Prague 2, Czech Republic, veselska@natur.cuni.cz Tomáš Kočí. Ivančická 581, Prague 9 Letňany, 19900 protula@seznam.cz Jan Dudák. Institute of Experimental and Applied Physics, Czech Technical University in Prague, Husova 240/5, 11000 Prague, Czech Republic, jan.dudak@cvut.cz Martin Vohník. Institute of Botany, Czech Academy of Sciences, Lesní 322, 25243 Průhonice, Czech Republic, vohnik@ibot.cas.cz

Key words: x-ray micro-computed tomography; borings; burrows; epibionts; methodology

Submission: 27 November 2019. Acceptance: 18 April 2020.

\section{INTRODUCTION}

Micro-computed tomography (micro-CT) is a technique of displaying internal structures of an object using x-rays. An x-ray (radiography) system typically produces $2 \mathrm{D}$ shadow images of 3D structures, where depth information is completely lost. In contrast, an x-ray tomography system acquires many projection images taken from different angles by rotating the sample, and the resulting series is then reconstructed into cross-sectional images. These can be further analyzed, processed into 3D models, converted into movies, etc.

A wider utilization of computed tomography in paleontological studies started in the early 1980s, when the medical technology of $\mathrm{x}$-ray computed tomography was first applied to vertebrate fossils (Conroy and Vannier, 1984; Tate and Cann, 1982). Its intensive application continued through the beginning of the twenty-first century, with an increasing number of papers focusing on fossil plants (Friis et al., 2015; Mays et al., 2017), trace fossils (Beuck et al., 2008; Schönberg and Shields, 2008; Tapanila, 2008; Wisshak et al., 2017), and animals (e.g., Abel et al., 2012; Donoghue et al., 2006; Görög et al., 2012; Kachovich et al., 2019; Kellner et al., 2019; Pleissis and Broeckhoven, 2019). Additionally, some papers compared the permeability of $\mathrm{x}$-rays in different types of rocks (Carlson et al., 2003). Micro-CT is now being applied in several studies focusing on bioerosion of recent and fossil shell materials (Amon et al., 2015; Beuck et al., 2008; Färber et al., 2016; Wisshak et al., 2017). The recent enormous growth of its use in paleontological studies is mainly due to the increasing availability of relatively affordable microCT devices.
Bioerosion can be defined as the destruction and removal of consolidated mineral or lithic substrates by the direct action of organisms. In general, analysis of bioerosion is difficult, and traditional methods typically lead to destruction of the investigated specimen; these include microscopy (especially scanning electron microscopy, SEM), thin sectioning and vacuum cast-embedding (Golubić et al., 1975, 1981; Wisshak, 2012). There are many papers applying and discussing microCT as a suitable method for bioerosion analysis. For example, advanced segmentation techniques and their use for morphometric analyses were presented on an example of Cretaceous belemnite (Wisshak et al., 2017); the 'ambient occlusion' algorithm was tested by (Titschack et al., 2018) as the segmentation tool of choice for bioerosion analyses; the application of CT volume data for computing bioerosion rates was presented by Färber et al. (2016); and the CT processing technique, previously tested in coral research, was applied to facilitate the characterization of the ichnological signature of cores from modern marine soft sediments by Dorador et al. (2020).

In the present study, a large set (more than 60 specimens) of paleontological and recent samples with various materials of shells and tunnel infillings, as well as with different sizes of the studied objects and their internal structures, were scanned with the aim of testing the benefits and limitations of micro$\mathrm{CT}$ in imaging traces of various biological activities related to bioerosion (borings, burrows, and epibionts). Additionally, fossils of a wide age range were studied to test how diagenesis and various environmental conditions had affected their colonization and decomposition. 


\section{MATERIAL AND METHODS}

A set of samples ranging from the Middle Ordovician to recent age was gathered to cover various materials of shells, influenced by borings, burrows, and epibionts (Table 1).

This study was performed using an $\mathrm{x}$-ray micro-tomograph SkyScan 1172 (micro-CT) at the National Museum in Prague, Czech Republic, with a tungsten source, a $5 \mu \mathrm{m}$ focal spot, and a CCDbased $x$-ray camera with an 11 megapixel sensor (4000 $\times 2664$ pixels, $9 \mu \mathrm{m}$ pixel pitch).

The first and most time-consuming step was obtaining a series of $x$-ray images (Table 1). Several hundreds to thousands of $x$-ray transmission projections in equitant angular views resulted from the scanning (Figure 1). Adjusted settings of the micro-CT device for each type of the examined material are described in Table 2.

The material is housed in the National Museum, Prague, Czech Republic (NMP) and in the palaeontological collections of the Musée VertMuséum d'Histoire naturelle du Mans (Sarthe, France), bearing registration numbers MHNLM EMV 2016.3.14, 40, 44. The material was also studied using an Olympus SZX 12 stereomicroscope. Photographs were taken with a Canon 6D camera. Ammonium chloride whitening, a method commonly used by invertebrate palaeontologists
(Parsley et al., 2018), was employed to enhance morphological details of the fossils.

In the course of the following reconstruction, $\mathrm{N}-$ Recon software was used (SkyScan, 2003); it produced a 3D dataset, which can be stored to the computer hard drive as a set of tiff or bmp images representing virtual slices of the scanned specimen (Figure 1C).

For subsequent creation of a complete 3D representation of internal microstructures, Avizo 9.5 software (Thermo Fisher Scientific) was applied. Volume rendering (Figure 1D) was used for reconstruction of the investigated object; slices through the $x, y$, and $z$ planes were used to create cross sections.

\section{RESULTS OF WORKFLOW OPTIMIZATION}

\section{Preparation and Scanning Process}

An optimal holder is needed for a successful scan. Larger samples can be fixed in a special polystyrene chamber without the use of an adhesive (Figure 2A). Polystyrene (styrofoam) is an excellent material from which to make sample holders for use in the micro-CT device; it is freely available as scrap almost everywhere, is completely transparent to $x$-rays and therefore invisible in the subsequent reconstruction, and can be eas-

TABLE 1. Samples investigated in this study using micro-CT. For the first time, such a large set of more than 60 specimens from nine different materials was investigated using this technique.

\begin{tabular}{|c|c|c|c|c|}
\hline $\begin{array}{c}\text { Case } \\
\text { studies }\end{array}$ & material & age & country & locality \\
\hline 1 & $\begin{array}{l}\text { Internal moulds of invertebrate body fossils } \\
\text { preserved in the siliceous nodules }\end{array}$ & $\begin{array}{l}\text { Middle } \\
\text { Ordovician }\end{array}$ & Czechia & $\begin{array}{l}\text { Díly, Rokycany, Praha-Šárka, } \\
\text { Osek }\end{array}$ \\
\hline 2 & Bryozoan colony of/in marls to clayey limestones & $\begin{array}{l}\text { Middle } \\
\text { Ordovician }\end{array}$ & Russia & $\begin{array}{l}\text { Khrevitsa-St. Petersburg } \\
\text { Region }\end{array}$ \\
\hline 3 & $\begin{array}{l}\text { Epibiontic interactions of bryozoan colonies and } \\
\text { conulariid specimens from clayey limestones }\end{array}$ & $\begin{array}{l}\text { Upper } \\
\text { Ordovician }\end{array}$ & Czechia & Loděnice \\
\hline 4 & Apatitic periderm of conulariids & $\begin{array}{l}\text { Upper } \\
\text { Ordovician }\end{array}$ & Czechia & $\begin{array}{l}\text { Praha-Libeň, Praha- } \\
\text { Palmovka, Vráž, Loděnice }\end{array}$ \\
\hline 5 & $\begin{array}{l}\text { Calcareous shells of platycerid gastropods from } \\
\text { organodetritic limestones }\end{array}$ & Lower Devonian & Czechia & Koněprusy \\
\hline 6 & Peloidal grainstone & Middle Devonian & Czechia & $\begin{array}{l}\text { Eifelian, ensensis conodont } \\
\text { Zone, Jirásek quarry, } \\
\text { Koněprusy area }\end{array}$ \\
\hline 7 & Calcitic or calcitic/aragonitic serpulid tube worms & $\begin{array}{l}\text { Upper } \\
\text { Cretaceous }\end{array}$ & France & $\begin{array}{l}\text { Gazonfier/Yvré-l'Évêque, Le } \\
\text { Mans region }\end{array}$ \\
\hline 8 & $\begin{array}{l}\text { Organic-walled egg-like bodies in lacustrine } \\
\text { sediments }\end{array}$ & $\begin{array}{l}\text { uppermost } \\
\text { Pleistocene }\end{array}$ & Czechia & Stará Jímka core \\
\hline 9 & $\begin{array}{l}\text { Recent calcareous large foraminifers from } \\
\text { Posidonia oceanica seagrass meadows }\end{array}$ & recent & Malta & Mediterranean Sea \\
\hline
\end{tabular}



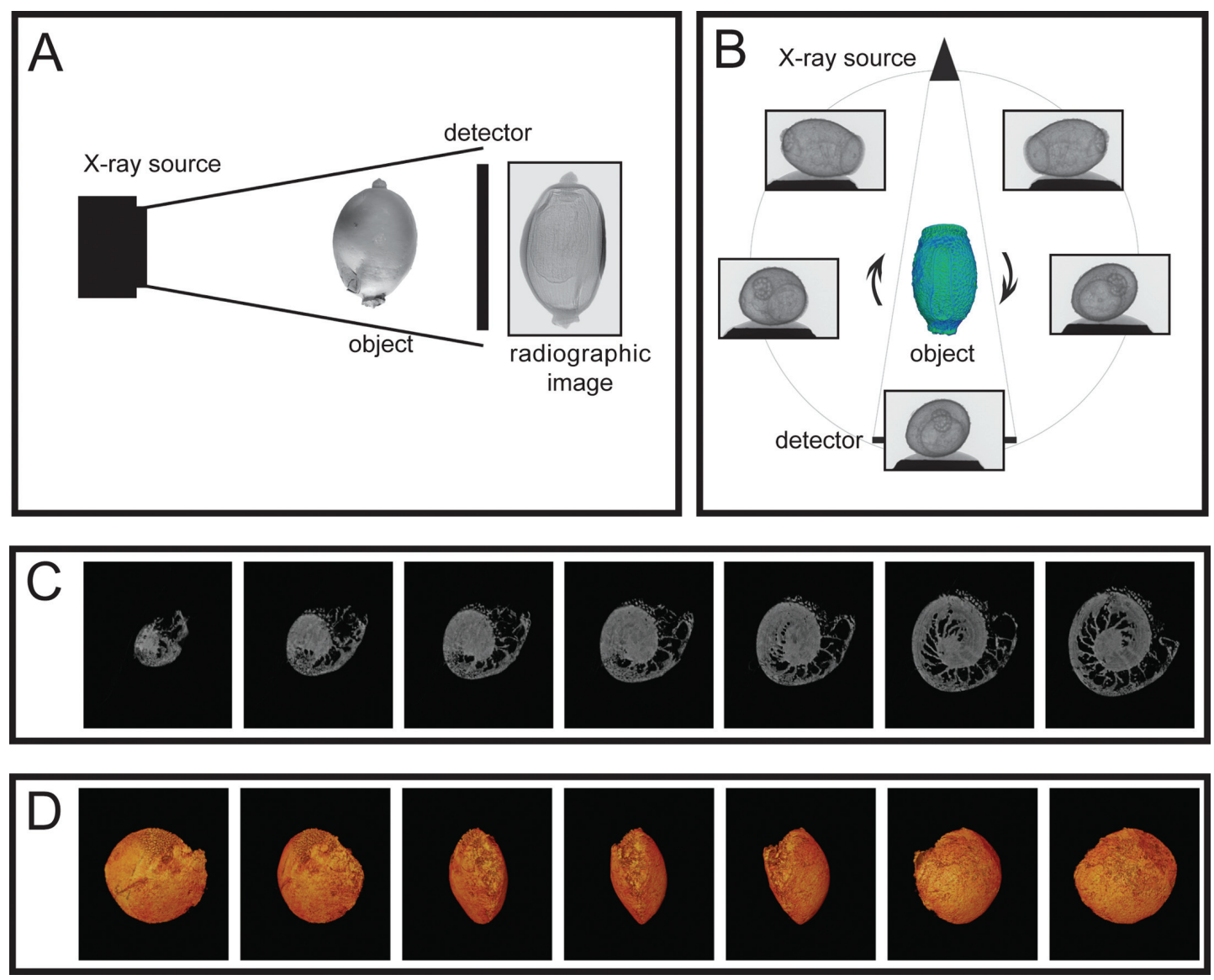

FIGURE 1. (A) Single $x$-ray projection. Schematic representation of positioning of the investigated object inside $x$-ray device. (B) Multiple x-ray projections as the object rotates. Positioning of investigated object inside micro-CT device. (C) Example of 3D dataset, i.e., a group of 2D slice images acquired by the MicroCT scanner. (D) Examples of Volume rendering; technique in visualization and computer graphics, used to display object from 3D data set in different aspects and orientations.

ily cut to any desired shape. Cutting is best done with a (not too) hot knife. This seals the cut surface and prevents polystyrene particles from getting loose and accumulating in the scanning chamber. Cold cutting leaves a rough surface, which easily sheds polystyrene particles.

For each specimen, it was necessary to prepare an individual polystyrene chamber with the aid of a heated blade edge (Figure 2A-B). During scanning, unexpected movement of the investigated sample must be avoided and, therefore, it is necessary to stabilize the sample with the help of small polystyrene pieces. Re-using an older polystyrene chamber is not recommended, as rock particles from the previous scanning may interfere with the reconstructed specimen. Polystyrene can also be successfully replaced by suitable flower arrangement materials.

Small objects such as shells of foraminifers (about $1 \mathrm{~mm}$ in diam.) were mounted on custom- made thin metal stubs using nail polish (Figure 2C). After scanning, the samples were removed from the holders by dissolving the polish with acetone. It is recommended to first test the investigated material for acetone-solubility; for example, acetone bath is suitable for recent calcareous foraminifers and charcoal specimens. Plastic tubes allow more samples to be scanned at once (Figure 2D).

Since any material in micro-CT is defined by its density and atomic number, the results depend critically on the contrast in density and atomic number between the fossil material and the respective boring infilling. The contrast can be enhanced by using a filter (Table 3 ). With growing x-ray absorption of the material, it is recommended to use filters in the following order: no filter, Al $0.25 \mathrm{~mm}$, Al 0.5 $\mathrm{mm}$, combined filter $\mathrm{Al}+\mathrm{Cu}$ and simple filter $\mathrm{Cu}$ $1 \mathrm{~mm}$ (SkyScan, 2003). Specimens with low x-ray absorption or material compositions with low aver- 
TABLE 2. Suggested settings of micro-CT for selected types of material. Comments for the respective columns: Filter: The $x$-ray beam energy can be modified using different beam filters. Voltage source and current: Specimens with lesser or greater $\mathbf{x}$-ray permeability require adjusting the energy of the $\mathrm{x}$-rays. The $\mathrm{x}$-ray beam energy can be modified by altering voltage to the tube. Increasing voltage also means decreasing current. Random movement: Very small, regular movements of specimens help to compensate for mechanical inaccuracies in micro-CT. Rotation step: The rotation step determines how much the sample rotates between images.

\begin{tabular}{|c|c|c|c|c|c|c|c|}
\hline $\begin{array}{l}\text { Case } \\
\text { studies }\end{array}$ & Type of material & Filter & $\begin{array}{l}\text { Specimen } \\
\text { size }\end{array}$ & $\begin{array}{l}\text { Voltage source/ } \\
\text { current source }\end{array}$ & $\begin{array}{c}\text { Random } \\
\text { movement }\end{array}$ & $\begin{array}{l}\text { Rotation step } \\
\text { (degree) }\end{array}$ & $\begin{array}{c}\text { Image pixel } \\
\text { size }(\mu \mathrm{m})\end{array}$ \\
\hline 1 & $\begin{array}{l}\text { Internal moulds of } \\
\text { siliceous nodules }\end{array}$ & $\mathrm{Cu} 1 \mathrm{~mm}$ & $1-5 \mathrm{~cm}$ & $\begin{array}{c}100 \mathrm{kV} / 120-124 \\
\mu \mathrm{A}\end{array}$ & 10 & 0.2 & $3-13$ \\
\hline 2 & $\begin{array}{l}\text { Marls to clayey } \\
\text { limestones }\end{array}$ & $\mathrm{Cu} 1 \mathrm{~mm}$ & $5 \mathrm{~cm}$ & $100 \mathrm{kV} / 100 \mu \mathrm{A}$ & 10 & 0.3 & $27.08 \mu \mathrm{m}$ \\
\hline 3 & Clayey limestones & Cu 1 mm & $3-5 \mathrm{~cm}$ & $100 \mathrm{kV} / 100 \mu \mathrm{A}$ & 1 & 0.2 & 13.5 \\
\hline 4 & Apatitic periderm & Al $0.5 \mathrm{~mm}$ & $3-10 \mathrm{~mm}$ & $\begin{array}{c}49-80 \mathrm{kV} / 124- \\
200 \mu \mathrm{A}\end{array}$ & $1-5$ & $0.2-0.22$ & $2.06-2.84$ \\
\hline 5 & $\begin{array}{l}\text { Organodetritic } \\
\text { limestones }\end{array}$ & $\mathrm{Al}+\mathrm{Cu}$ & $3-5 \mathrm{~mm}$ & $\begin{array}{c}80-100 \mathrm{kV} / 100- \\
124 \mu \mathrm{A}\end{array}$ & 2 & 0.2 & $0.95-2.34$ \\
\hline 6 & Limestone & $\mathrm{Cu} 1 \mathrm{~mm}$ & $0.5 \mathrm{~cm}$ & $100 \mathrm{kV} / 100 \mu \mathrm{A}$ & 5 & 0.2 & 1.08 \\
\hline 7 & $\begin{array}{l}\text { Calcitic or calcitic/ } \\
\text { aragonitic serpulid } \\
\text { tube worms }\end{array}$ & Al $0.5 \mathrm{~mm}$ & $1-2 \mathrm{~cm}$ & $80 \mathrm{kV} / 124 \mu \mathrm{A}$ & 10 & 0.2 & 4 \\
\hline 8 & $\begin{array}{l}\text { Organic-walled egg- } \\
\text { like bodies }\end{array}$ & no filter & $0.2 \mathrm{~mm}$ & $40 \mathrm{kV} / 250 \mu \mathrm{A}$ & 0 & 0.2 & 0.54 \\
\hline 9 & Foraminifers & Al $0.25 \mathrm{~mm}$ & $1.5 \mathrm{~mm}$ & $59 \mathrm{kV} / 167 \mu \mathrm{A}$ & 5 & 0.2 & 1 \\
\hline
\end{tabular}

age atomic number (e.g., the organic-walled egglike bodies) are typically scanned without any filter. On the other hand, a $\mathrm{Cu} 1 \mathrm{~mm}$ filter is typically used for specimens with high x-ray absorption of the material (e.g., clayey limestones and apatitic periderm) (Table 2).

\section{Reconstruction and Visualization}

Individual trace fossils inside the shells were highlighted during the visualizing processes with the help of Avizo 9.5 software. The studied materials and fossils were examined with the use of Volume rendering and Ortho-slice mode surfaces and/ or cut sections. Likewise, Isosurface visualising of
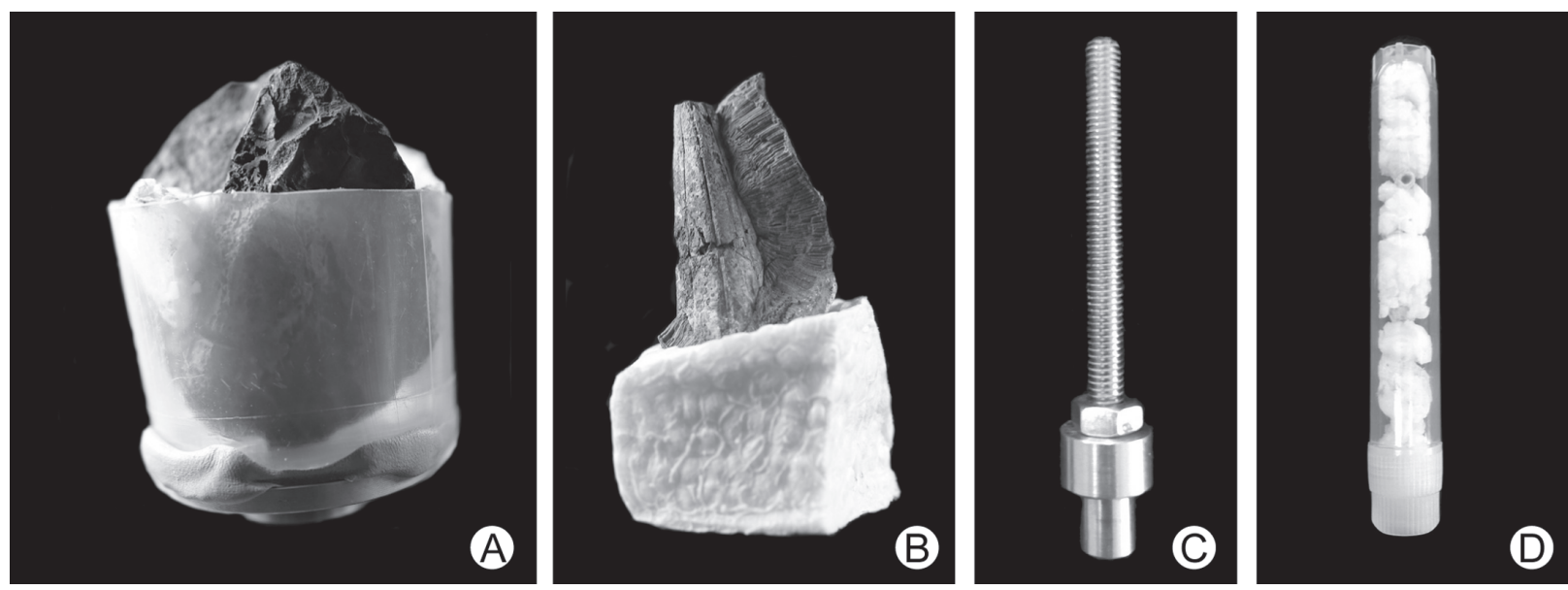

FIGURE 2. Custom-made holders specially adapted for each scanned specimen. (A) Plastic cup. (B) Polystyrene holder. (C) Aluminum holder for small specimens. (D) Plastic tube filled with polystyrene. 
TABLE 3. Glossary. Explanation of terms used in the present paper.

\begin{tabular}{|c|c|}
\hline 3D d & $\begin{array}{l}\text { The final result of a CT scan. It is a product of dedicated software processing called tomographic } \\
\text { reconstruction. It is a 3D voxel-based model of the scanned object. } \\
\text { A 3D dataset is typically stored and used as a set of digital images representing virtual cross-sections } \\
\text { of the scanned object. }\end{array}$ \\
\hline Avizo & $\begin{array}{l}\text { Software application which enables users to perform interactive visualization and computation on } 3 \mathrm{D} \\
\text { data sets. }\end{array}$ \\
\hline Bioerosion & Destruction and removal of a consolidated mineral or lithic substrate by the direct action of organisms. \\
\hline Filter & $\begin{array}{l}\text { The x-ray beam energy can be modified using different beam-filters. There are two basic filters in the } \\
\text { Skyscan } 1172 \text { tomograph built into the device. Besides the default setting (no filter), there is a } 0.5 \mathrm{~mm} \\
\text { aluminium filter and a combined } 1 \mathrm{~mm} \text { copper + aluminium filter. However, the majority of our studied } \\
\text { fossil materials required the use of additional custom-made filters, because of a low x-ray permeability } \\
\text { of the samples. }\end{array}$ \\
\hline Ortho-slice & Techniques of visualization and computer graphics creating slices through the $x, y$, and $z$ planes. \\
\hline $\begin{array}{l}\text { Oversize scan and } \\
\text { off-set mode }\end{array}$ & $\begin{array}{l}\text { For large samples, Oversize scans, in some cases in combination with Off-set mode were used. This } \\
\text { functionality of the SkyScan } 1172 \text { allows automatic imaging of the sample in two or more sections } \\
\text { sequentially, and their subsequent merging during the reconstruction process into a single volume. }\end{array}$ \\
\hline ement & $\begin{array}{l}\text { Very small, regular moving of specimen helping in compensation of mechanical inaccuracies in micro- } \\
\text { CT. }\end{array}$ \\
\hline Rotation step & The rotation step (measured in degrees) determines how much the sample rotates between images. \\
\hline Segm & $\begin{array}{l}\text { Segmentation assigns a label to each part of the image that belongs to the material under } \\
\text { investigation. The aim of segmentation is to display the selected inner part of the object (the most } \\
\text { common are, for example, the internal organs of animals). The images from the } 3 D \text { dataset are } \\
\text { scrolled step by step, and each image is manually colored. }\end{array}$ \\
\hline Scanning process & Comprises all steps when the object is inside an x-ray device. \\
\hline $\begin{array}{l}\text { Tomographic } \\
\text { reconstruction }\end{array}$ & $\begin{array}{l}\text { A set of dedicated mathematical algorithms creating } 3 \mathrm{D} \text { model of the scanned object using a set of } \\
\text { acquired } 2 \mathrm{D} \text { x-ray images. }\end{array}$ \\
\hline $\begin{array}{l}\text { Voltage source/ } \\
\text { current }\end{array}$ & $\begin{array}{l}\text { Specimens of lower or higher } x \text {-ray density require the adjustment of energy of the } x \text {-rays. The x-ray } \\
\text { beam energy can be modified by varying voltage to the tube. Selective removing of the low x-rays } \\
\text { energy beams by filters increases mean x-ray beam energy. For each filter, a suitable voltage value is } \\
\text { recommended. Increasing voltage decreases current and vice versa. }\end{array}$ \\
\hline Volume rendering & $\begin{array}{l}\text { A set of techniques in scientific visualization and computer graphics, used to display an object from the } \\
3 \mathrm{D} \text { data set. }\end{array}$ \\
\hline Voxel & $\begin{array}{l}\text { Voxel is the smallest building block of 3D digital data. It is a volumetric equivalent of an image pixel. } \\
\text { Unlike a pixel, voxel has three usually isotropic dimensions and can be, therefore, understood as a } \\
\text { small cube providing information on a certain position in a 3D space. }\end{array}$ \\
\hline$X$-ray image & Two-dimensional shadow images of 3D structures produced by $\mathrm{x}$-ray. \\
\hline
\end{tabular}

$3 \mathrm{D}$ images and manually operated segmentation were found to be very useful.

Opportunities for the volumetric rendering using micro-CT are illustrated by the following case studies (Table 4).

Invertebrate body fossils from siliceous nodules (Czechia). In siliceous nodules of the Šárka Formation (Middle Ordovician, Darriwilian, Czechia), body fossils of invertebrates occur mostly preserved as internal moulds with dissolved shells or exoskeletons (Figure 3A, 3C). Very often, a diverse ichnoassemblage is mostly observable as empty or partly filled tunnels with different matrix (Figure 3B, 3D, 3E).
Thanks to the contrast in density and atomic number between the fossil material and empty or partly filled burrows, it is possible, using micro-CT, to detect diverse systems of simple (Palaeophycus) or complex (Arachnostega, Pilichnus) trace fossils (Kraft et al., 2019).

Avizo 9.5 software was applied, and in this particular case, the time-consuming segmentation process was replaced by the following procedure: Attaching Filter Sandbox module, using Median filter, changing to appropriate threshold, and then generating Isosurface module with front face. The described steps allowed visualization of burrowing feeding traces faster than using segmentation. 
TABLE 4. Overview of the selected types of materials investigated in this study.

\begin{tabular}{|c|c|c|c|c|c|c|c|c|}
\hline 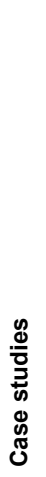 & 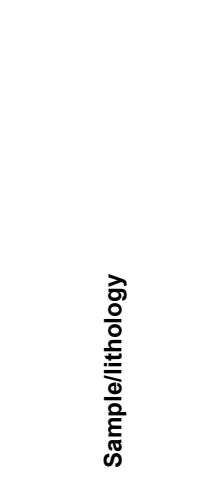 & 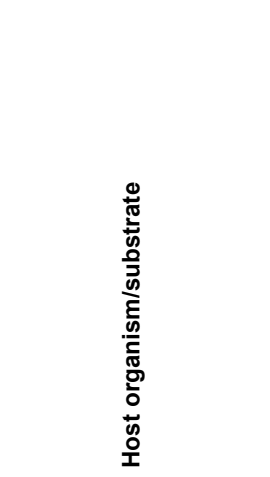 & 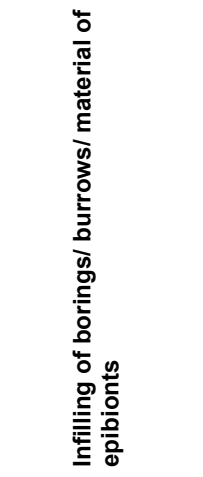 & 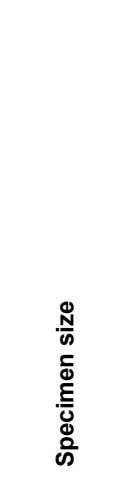 & 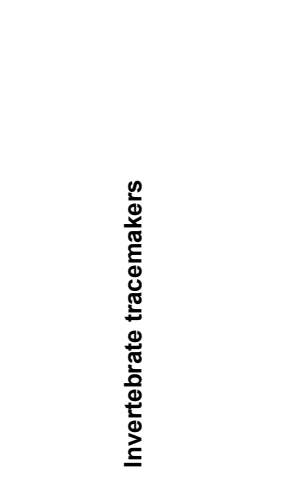 & 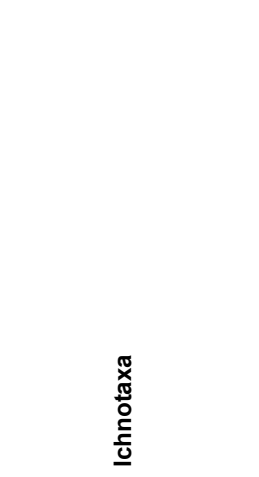 & 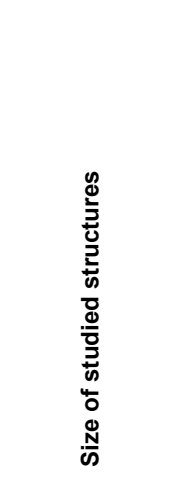 & 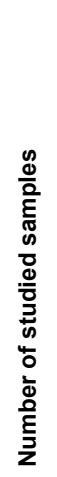 \\
\hline 1 & $\begin{array}{l}\text { Siliceous } \\
\text { nodules of the } \\
\text { Šárka } \\
\text { Formation }\end{array}$ & $\begin{array}{l}\text { Internal moulds of } \\
\text { invertebrates }\end{array}$ & Empty & $1-5 \mathrm{~cm}$ & $\begin{array}{l}\text { Unknown organisms } \\
\text { (?Polychaeta) }\end{array}$ & $\begin{array}{l}\text { Arachnostega } \\
\text { Pilichnus } \\
\text { Palaeophycus }\end{array}$ & $0.5-3 \mathrm{~mm}$ & 29 \\
\hline 2 & $\begin{array}{l}\text { Marls to clayey } \\
\text { limestones }\end{array}$ & Bryozoan colony & $\begin{array}{l}\text { Light-grey } \\
\text { clayey } \\
\text { limestone } \\
\text { (same as the } \\
\text { specimen) }\end{array}$ & $5 \mathrm{~cm}$ & clionaid sponges & $\begin{array}{l}\text { Entobia } \\
\text { cf.devonica }\end{array}$ & $2.5 \mathrm{~mm}-1 \mathrm{~cm}$ & 1 \\
\hline 3 & $\begin{array}{l}\text { Clayey } \\
\text { limestones }\end{array}$ & $\begin{array}{l}\text { Conulariid walls } \\
\text { (apatite) of } \\
\text { Archaeoconularia } \\
\text { fecunda }\end{array}$ & $\begin{array}{l}\text { Clayey } \\
\text { limestones }\end{array}$ & $3-5 \mathrm{~cm}$ & Epizoic bryozoans & Not determined & $3-5 \mathrm{~cm}$ & 3 \\
\hline 4 & $\begin{array}{l}\text { Apatitic } \\
\text { periderm }\end{array}$ & $\begin{array}{l}\text { Fragments of } \\
\text { conulariid periderm }\end{array}$ & $\begin{array}{l}\text { Empty or filled } \\
\text { by siltstone }\end{array}$ & $3-10 \mathrm{~mm}$ & Unknown organism & Not determined & $5-20 \mu \mathrm{m}$ & 4 \\
\hline 5 & $\begin{array}{l}\text { Organodetritic } \\
\text { limestones }\end{array}$ & $\begin{array}{l}\text { Fragments of } \\
\text { platycerid gastropod } \\
\text { shells }\end{array}$ & $\begin{array}{l}\text { Empty or filled } \\
\text { by } \\
\text { organodetritic } \\
\text { limestone }\end{array}$ & $3-5 \mathrm{~mm}$ & Unknown organism & Not determined & $5-20 \mu \mathrm{m}$ & 3 \\
\hline 6 & Limestone & Sparite & Sparitic calcite & $0.5 \mathrm{~cm}$ & $\begin{array}{l}\text { Cyanobacteria, } \\
\text { Fungi }\end{array}$ & Not determined & $30 \mu \mathrm{m}$ & 1 \\
\hline 7 & $\begin{array}{l}\text { Calcitic or } \\
\text { calcitic/ } \\
\text { aragonitic }\end{array}$ & $\begin{array}{l}\text { Serpulid tube worms } \\
\text { Pyrgopolon } \\
\text { (Pyrgopolon) } \\
\text { deforme }\end{array}$ & Empty & $1-2 \mathrm{~cm}$ & $\begin{array}{l}\text { Barnacles, clionaid } \\
\text { sponges, } \\
\text { polychaetes, } \\
\text { sipunculans }\end{array}$ & $\begin{array}{l}\text { Rogerella, } \\
\text { Entobia, } \\
\text { Trypanites, } \\
\text { Maeandropolydora }\end{array}$ & $100 \mu \mathrm{m}$ & 15 \\
\hline 8 & Siltstone & $\begin{array}{l}\text { Organic-walled egg- } \\
\text { like bodies } \\
\text { presumed chitin } \\
\text { composition }\end{array}$ & Empty & $0.2 \mathrm{~mm}$ & $\begin{array}{l}\text { Probable endoliths } \\
\text { belonged to Fungi }\end{array}$ & Not determined & $1 \mu \mathrm{m}$ & 3 \\
\hline 9 & Calcite & Foraminifers Sorites & Empty & $1.5 \mathrm{~mm}$ & $\begin{array}{l}\text { Probably green } \\
\text { algae, cyanobacteria } \\
\text { or perhaps also fungi }\end{array}$ & Not determined & $10 \mu \mathrm{m}$ & 3 \\
\hline
\end{tabular}

Ordovician bryozoan colony from marls to clayey limestones (Russia). The examined specimens represent one half of a hemispherical bryozoan colony from the marls to clayey limestones around the village of Khrevitsa (Russia) (the socalled Khrevitsa Formation). The fauna of this locality points to the Darriwilian (Middle Ordovician). The holes bored in bryozoans are filled with light-grey clayey limestone, which weathers out at almost exactly the same speed as the bryozoan skeleton; therefore, the borings are not observable in either fresh or weathered material. Nearly all bryozoans of this shape and age are bored, but except for the micro-CT, there is no way to examine the shape (and thereby, ichnotaxonomy and tracemaker) non-destructively. With the use of micro-CT, tubular, slightly curved borings of two different diameters are recognizable (Figure 4); in addition, a couple of roughly ovoid chambers, larger than $5 \mathrm{~mm}$ are visible. The thinnest, gener- 

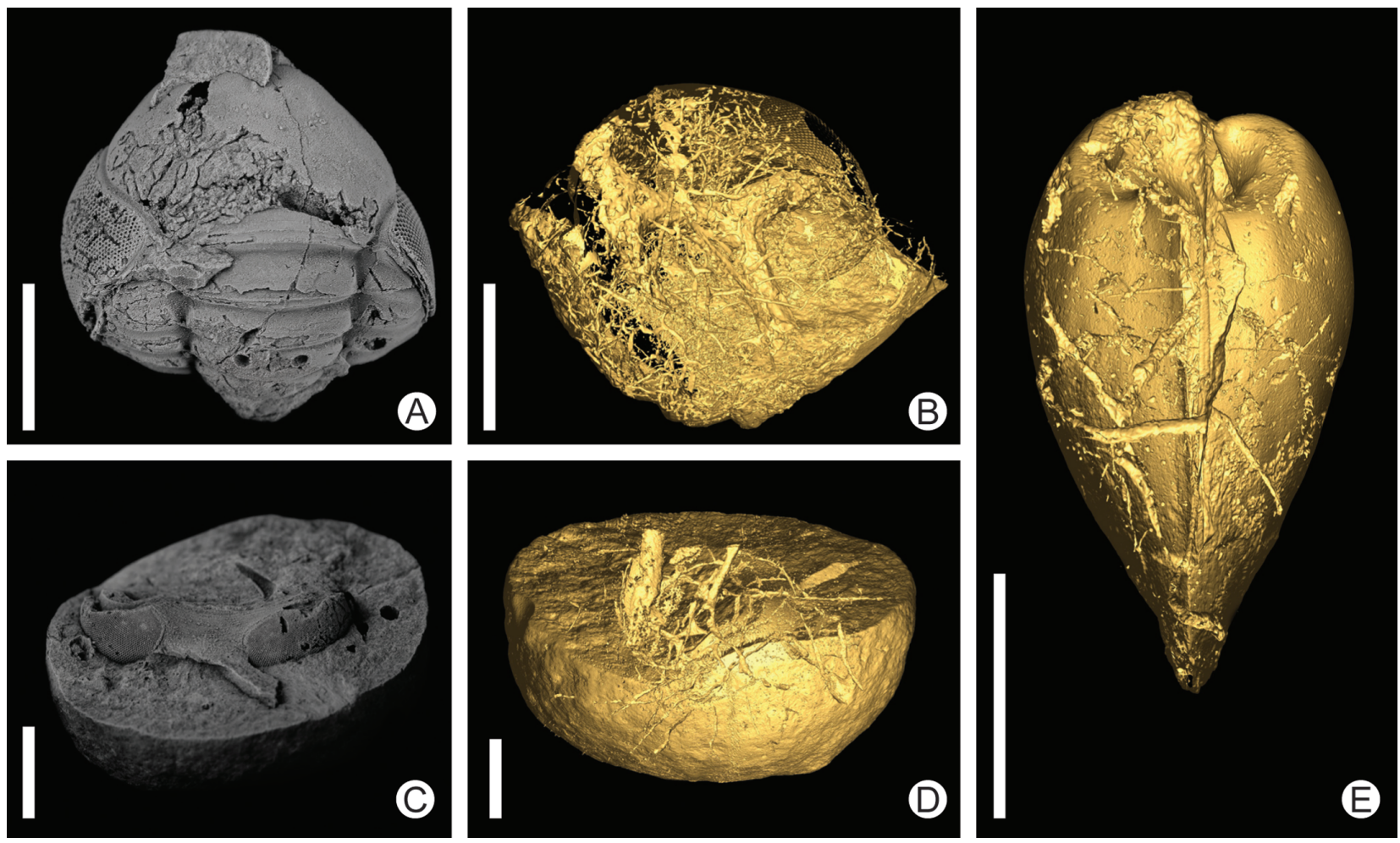

FIGURE 3. Siliceous nodules of the Šárka Formation. (A, B) Pricyclopyge binodosa, complete trilobite, no. NMP L 35055, locality Praha-Šárka, Middle Ordovician (Darriwilian), (A) Enrolled trilobite coated with ammonium chloride, exterior of objects. (B) Micro-CT image showing dense burrows, interior of objects. (C, D) Rostrum with eyes of a trilobite $P$. binodosa, no. NMP L46892, locality Praha-Šárka, Middle Ordovician (Darriwilian). (C) Rostrum coated with ammonium chloride, exterior of objects. (D) Micro-CT visualization of tunnels, interior of objects. (E) Bivalve Redonia deshayesi, micro-CT image showing trace fossils, interior of objects, no. NMP L 51722, locality Osek, Middle Ordovician (Darriwilian). All scale bars equal $5 \mathrm{~mm}$.

ally radial tunnels/exploratory threads show diameters of $2.5 \mathrm{~mm}$; the sizes of the largest chambers lying outside the plane of the cut (i.e., visible on micro-CT image Figure 4) are estimated at $9.5 \mathrm{~mm}$. The largest size of a cut chamber is $7.6 \mathrm{~mm}$. These hollows can be interpreted as chambers (borings) of clionaid sponges close to the presumed tracemakers of the ichnotaxon Entobia devonica (Schönberg and Shields, 2008); it would make the depicted bryozoan with its boring the so far oldest record of boring sponges.

Ordovician bryozoan colonies from clayey limestones (Czechia). Samples of minute conulariid Archaeoconularia fecunda specimens from the Zahořany Formation (Upper Ordovician, Katian, Czechia) overgrown by a bryozoan colony preserved in clayey limestones were scanned (Figure 5A-B). Micro-CT scanning showed internal structures of these probably commensalitic relationships between the bryozoan colony and small conulariids. In this particular case, large samples with high demands on the resulting image quality

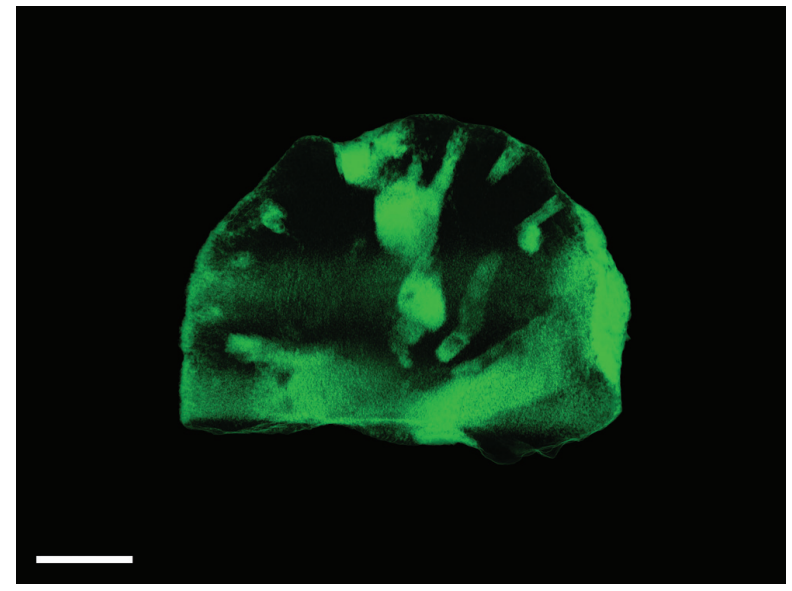

FIGURE 4. Ordovician bryozoan colony. One-half of hemispherical bryozoan, interior of object, bearing probably oldest boring attributable to ichnogenus Entobia Bronn, 1837. Besides semi-radial tunnels and exploratory threads, three bulbous chambers discovered near the center of the hemisphere. Darriwilian (middle Ordovician), Khrevitsa locality, St. Petersburg Region, Russia. Scale bar equals $1 \mathrm{~cm}$. 


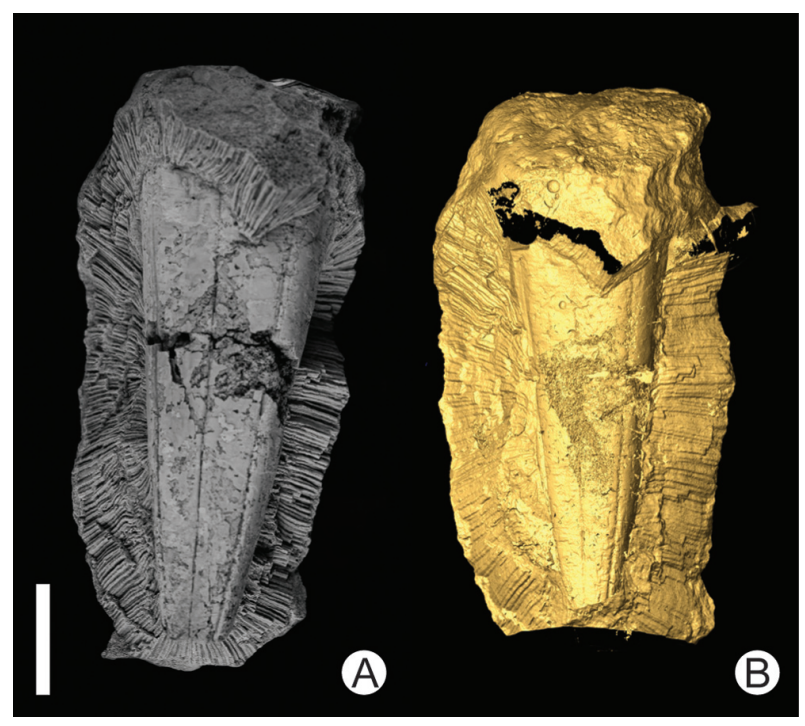

FIGURE 5. Minute conulariid specimen. (A) Conulariid specimen of Archaeoconularia fecunda and trepostome bryozoan colony; coated with ammonium chloride, no. NMP L21990, locality Loděnice, Upper Ordovician, Zahořany Formation (lower Katian) (B) Micro-CT visualizing of inner surfaces. Scale bar equals $5 \mathrm{~mm}$.

were scanned as oversize scans with additional $\mathrm{Cu}$ $1 \mathrm{~mm}$ filter and using camera's offset mode. The use of such device settings means a longer scan time. A long scan time is not desirable, as it causes artifacts and errors to increase. If the scan lasts longer than one day, the sample may move in its holder, and various artifacts may be generated. Based on our experience, we recommend avoiding scans that last longer than 24 hours.

Cretaceous calcitic/aragonitic serpulid tubes (France). We focused on Pyrgopolon (Pyrgopolon) deforme, a serpulid species whose tube fragments are common in Cenomanian deposits (the Neocardioceras juddii zone) of Le Mans region (Gazonfier and Yvré l'Évêque, France) (Kočí et al., 2017). Pyrgopolon acted as small solid benthic islands for colonization by invertebrate fauna (Figure 6 ). The borings found in the tubes using micro-CT show relatively low diversity; nevertheless, several different, recurring shapes can be recognized: domichnia of acrothoracican female cirripedes (Rogerella), boring sponges (Entobia) and spionid or sipunculid annelids (Trypanites, Maeandropolydora). Dwelling structures of the ichnogenus Rogerella are the best preserved. The examined tubes are the oldest known case of interaction between boring barnacles (tracemakers of Rogerella) and serpulid worms. Encrusters are more diverse, represented by cheilostome and cyclostome bryozoan colonies, juvenile oysters, serpulid and sabellid worms, and foraminifers (Appendix 1).

Quaternary egg-like bodies built from organic matter with presumed chitin composition (Czechia). The isolated egg-like bodies (uppermost Pleistocene, from Stará Jímka core, mountain lake, Czechia) built from organic matter were scanned. Empty microboring structures were observed in these objects. The studied microfossils are presumed to have had chitin composition. In this particular case, a very small specimen was scanned in the micro-CT device as follows: The rotation step was reduced and the number of averaged frames per each angular position was increased. This setting ensures the highest possible quality.

The use of micro-CT enables recognition of the nearly parallel orientation of tunnels to the test surfaces. Therefore, we suggest a fungal or fungallike boring organism, which used the test substrate as a food source. The commonly used vacuum cast-embedding technique for such samples (Golubić et al., 1983) could not be utilized for organicwalled microfossils, because they are extremely fragile. Micro-CT is currently the only way to view tunnels inside tests.

Microboring tunnels on recent calcareous foraminifers (Malta). Two larger specimens of recent calcareous symbiont-bearing benthic Foraminifera (soritids) from the photic zone of the sub-tropic Mediterranean Sea (Malta) were examined (Figure $7 A-B)$. Microboring tunnels were observed in the calcitic test walls of foraminifers (Figure 7C-D). The tunnels are mostly either empty or partly filled with remains of the boring organisms (probably softbodied algae and/or cyanobacteria, perhaps also fungi). Non-destructive micro-CT enabled imaging of the tunnel positions inside the test walls, their bifurcations, etc.

\section{DISCUSSION}

Various imaging techniques are used for viewing scan results of microborings (Tapanila, 2008). Several methods are available for visualizing trace fossils left by microbioerosion agents in lithic substrates. These include stereomicroscopy, microscopy of petrographic thin sections, and SEM of casts obtained by the epoxy cast-embedding technique, and micro-CT (Wisshak, 2012). Combining micro-CT with traditional methods helps to distinguish and quantify fine morphological features of microboring within shell substrates.

Thin sectioning may also be applied for microbioerosion analyses. Compared to micro-CT, it suffers from the limitations inherent to any 2D 


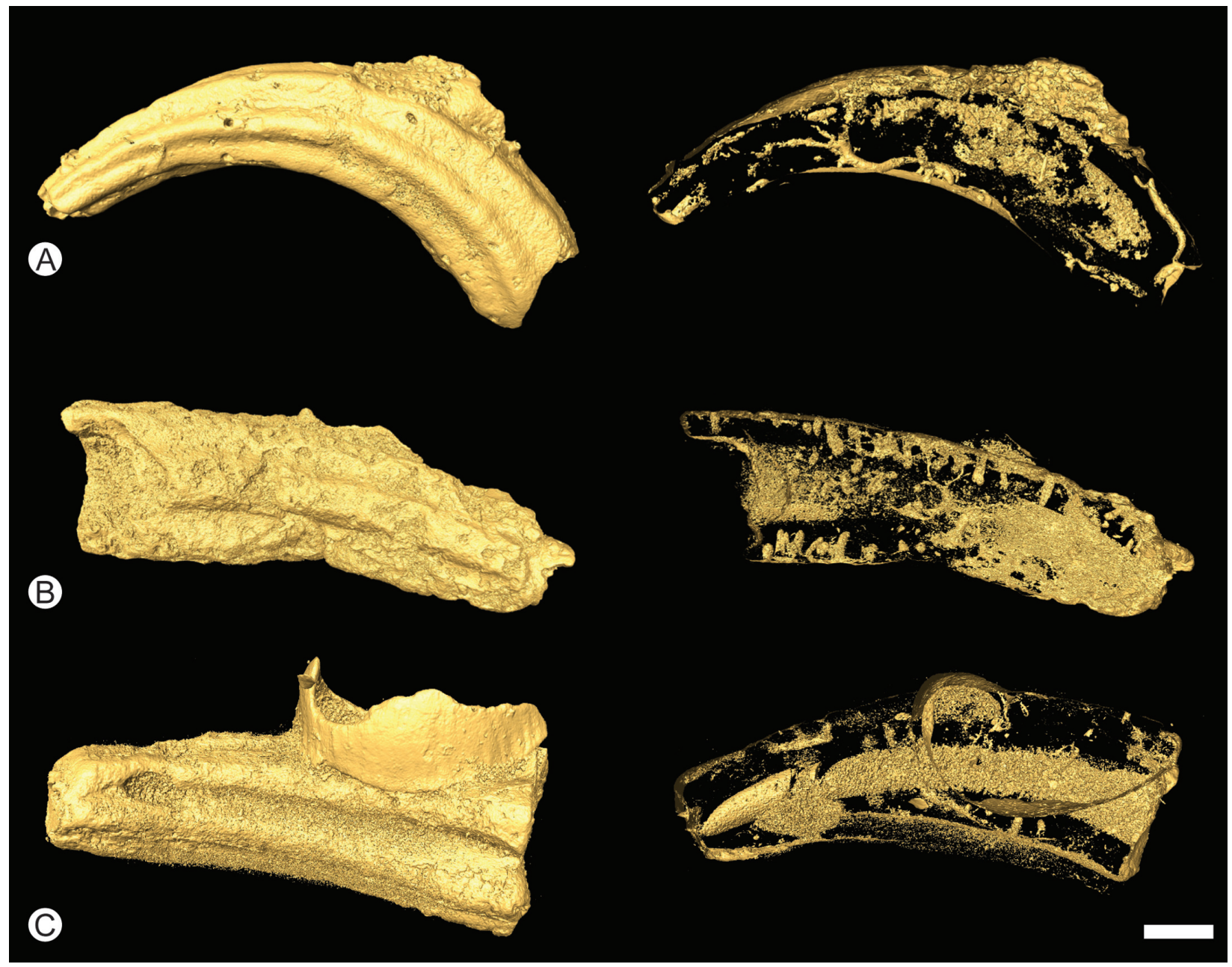

FIGURE 6. Tube fragments of the serpulid polychaete Pyrgopolon (Pyrgopolon) deforme. Left images show exterior of objects; right images show interior of objects. (A) Specimen encrusted with bryozoan colonies and serpulid worms, boreholes assigned to Entobia Bronn, 1837, representing the most common ichnogenus in the examined serpulid tubes, no. MHNLM EMV 2016.3.14. (B) Intensely bored specimen preserving tunnels of ichnogenera Entobia and Trypanites Mägdefrau, 1932, no. MHNLM EMV 2016.3.44. (C) Serpulid tube with Entobia boreholes and encrusting juvenile oyster, no. MHNLM EMV 2016.3.40. Scale bar equals $1 \mathrm{~cm}$.

visualization of 3D objects. Most microscopic borings have complex 3D geometries that are difficult to assess within a $30 \mu \mathrm{m}$ thick sheet of substrate, resulting in ambiguous ichnotaxonomic descriptions (Tapanila, 2008).

Vacuum cast-embedding is the process of filling cleaned tunnels with epoxy resin under vacuum conditions, and dissolving the substrate via treatment with diluted hydrochloric acid. This method does not necessarily require empty borings, albeit this is the ideal case; if the infill of the borings is permeable, it can be impregnated and does produce a suitable cast. This is, for instance, the case of fossils in upper Cretaceous white chalk (see Hofmann, 1996 for examples). The resulting casts can be studied with SEM in order to display even the most delicate morphological features. This is the most approved method for visualizing the 3D architecture of tunnel systems (Golubić et al., 1983; Wisshak, 2012). The fundamental difference is that vacuum cast-embedding is a destructive method, while micro-CT is a non-destructive one. While vacuum cast-embedding needs mainly empty tunnels, micro-CT is able to display tunnels filled with dense matrix. On the other hand, vacuum cast-embedding and SEM are able to display bioerosion with significantly better resolution than micro-CT.

Micro-CT provides full 3D renderings of microboring while maintaining context within the substrate. This is important for recognizing relationships between the trace fossil and the sub- 

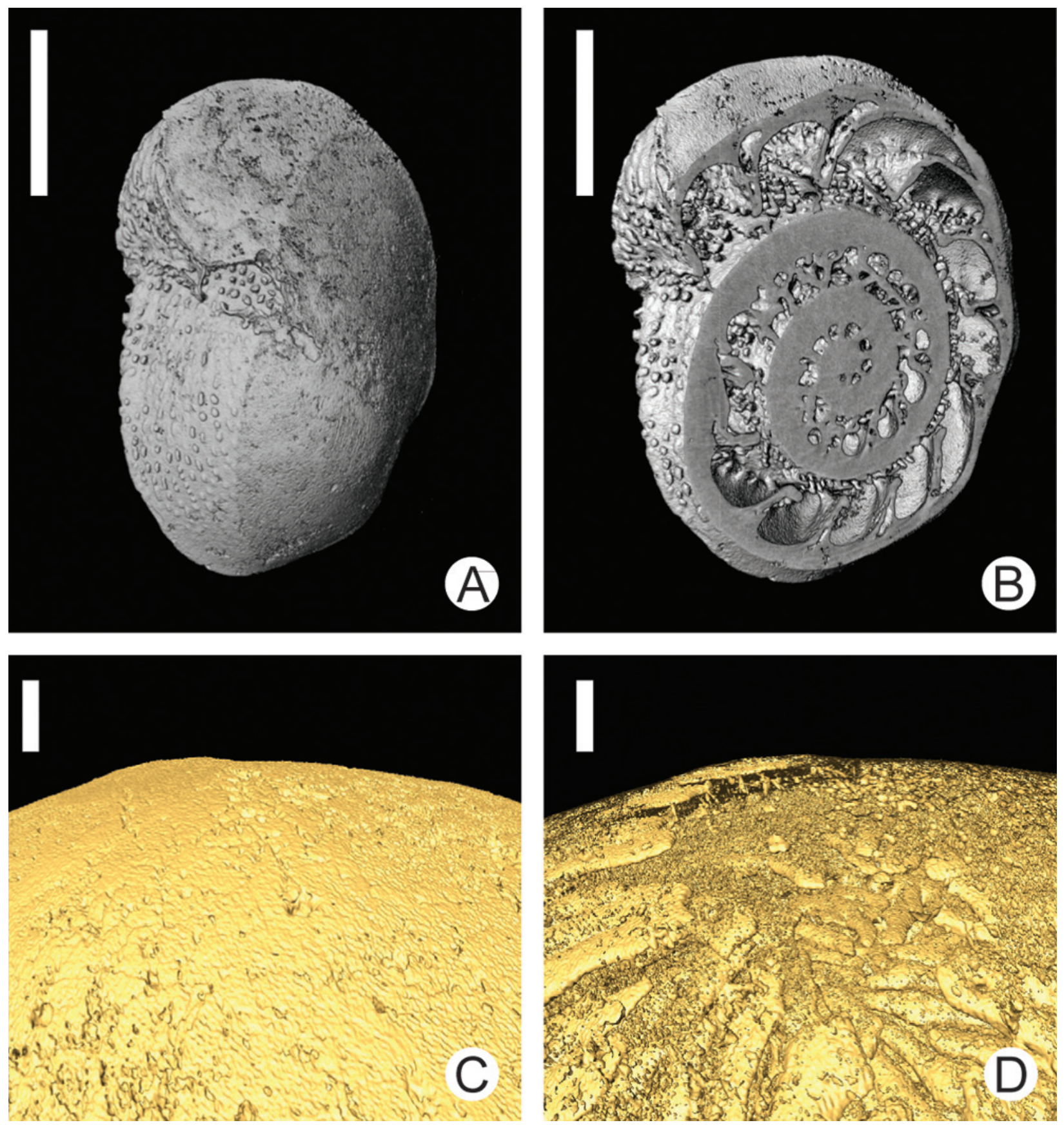

FIGURE 7. Three-dimensional visualization of a shell of the recent Foraminifera Amphistegina sp. illustrating the potential of micro-CT in investigations of recent marine shelled organisms. (A) A surface view of the whole shell. (B) A transversal section through the whole shell $(C, D)$ Details of the shells's surface.

strate. Compared to SEM and stereomicroscopy, micro-CT also has the advantage of allowing the object to be viewed in $3 \mathrm{D}$ through the full $360^{\circ}$ range (Tapanila, 2008).

Based on our research, we find micro-CT clearly the most suitable method for materials of invertebrate body fossils from siliceous nodules. Thanks to differences between empty or partly filled burrows, and internal moulds of fossils, diverse systems of simple (Palaeophycus) or complex (Arachnostega, Pilichnus) trace fossils can be visualized and identified. Likewise, our research has shown that micro-CT is the best method to visualize the shape of the borings in the Ordovician bryozoan colonies from the Khrevitsa Formation, because the holes bored in the bryozoans are filled 
with light-grey clayey limestone, which weathers out at almost exactly the same speed as the bryozoan skeleton.

The isolated egg-like bodies built from organic matter were scanned with micro-CT, because vacuum cast-embedding, a method commonly used for such samples (Golubić et al., 1983), was not feasible for these organic-walled microfossils. The samples were very small and brittle, and every handling posed a risk of the sample breaking apart. Micro-CT is overall a very low-risk investigative method, ideal for visualization of tunnels inside tests (Holcová et al., unpublished).

Micro-CT is a non-destructive method, so it is ideal for unique or rare specimens, especially those that need to be retained for further studies. Sample handling is only performed during preparation for scanning, and all other procedures, such as reconstruction, measurement, and segmentation, are only performed on a "virtual sample" or "virtual fossil" (Sutton et al., 2014). The virtual fossil can be transected in any direction, meaning that its internal structures can be studied in three dimensions. Distances within the "virtual sample" can be measured and volume measurements can be calculated. Individual parts, such as animal organs or borings can be segmented, that is, shown separately. Micro-CT is able to handle even very small samples (approx. $1 \mathrm{~mm}$ ), and show their internal structures and differentiation with relatively high resolution (approx. $0.5 \mu \mathrm{m}$ ).

The non-destructive nature is the greatest benefit of micro-CT. In paleontology, there is a lot of pressure to preserve the investigated specimen. It is often a single specimen, found after a long search, which cannot be replaced. Non-destructivity is also needed for museum practice: once a sample enters a museum's database, it becomes a subject of often strict regulations. Another important advantage is the possibility to completely repeat the research in case of doubts about the original investigation. Employing micro-CT as presented here allowed an interpretation of several different types of borings, burrows, and epibionts on shells of marine organisms that would otherwise not have been possible.

The most serious limits of micro-CT are related to resolution. The smallest achievable voxel size is related to the sample size and the detector field of view. The resolution partly depends on the sample size. In practice, micro-CT is not an optimal method for investigation of very small samples, where other devices, such as nano-CT or synchrotrons, are commonly used (Friis et al., 2015).
Results of x-ray scanning depend critically on contrast in density and atomic number between the fossil material and the boring infilling. Material discrimination ability in micro-CT is defined by the density and atomic number. If there is an insufficient contrast, a successful scan cannot be performed.

\section{CONCLUSIONS}

This paper presents $\mathrm{x}$-ray micro computed tomography techniques used for visualization of colonization and bioerosion structures of marine shelled organisms. A set of nine types of materials from a wide range of stratigraphic levels (Middle Ordovician-recent) and from different countries were examined. More than 60 specimens were scanned and to our knowledge, such a comprehensive comparison has never been done before. We present detailed settings of micro-CT devices for the nine types of materials, including preparation recommendations before scanning, and instructions for an easier and faster visualization of the samples. Our case studies illustrate the versatile use of micro-CT methodology. In some cases (e.g., Ordovician bryozoan colony from marls to clayey limestones), micro-CT was the sole method suitable for describing and determining the borings inside the host organism.

\section{ACKNOWLEDGMENTS}

This study was financially supported by the Czech Science Foundation (GACR18-05935S). Additional support was obtained from the institutional projects of the Czech Academy of Sciences, Institute of Botany (RVO 67985939), and Institute of Geology (RVO 67985831); Centre for Geosphere Dynamics (UNCE/SCl/006); Ministry of Culture of the Czech Republic (DKRVO 2019-2023/ 2.IV.b, National Museum, 00023272); PROGRES Q45; and European Regional Development Fund (Engineering applications of microworld physics,CZ.02.1.01/0.0/0.0/16_019/0000766). The authors wish to thank M. Wisshak and the anonymous reviewer for their thorough and inspiring reviews; $M$. Jäger for valuable comments on the systematics and the life style of serpulids; N. Morel for the stratigraphic notes of the Le Mans region; J. Bruthans for his valuable comments on the earlier versions of the manuscript; and S. Vodrážková for providing an access to some of the studied specimens. 


\section{REFERENCES}

Abel, R.L., Rettondini Laurini, C., and Richter, M. 2012. A paleobiologist's guide to 'virtual' microCT preparation. Palaeontologia Electronica, 15.2.6T:1-17. https://doi.org/10.26879/284 palaeo-electronica.org/content/issue-2-2012-technical-articles/233-micro-ct-workflow

Amon, D.J., Sykes, D., Ahmed, F., Copley, J.T., Kemp, K.M., Tyler, P.A., Young, C.M., and Glover, A.G. 2015. Burrow forms, growth rates and feeding rates of wood-boring Xylophagaidae bivalves revealed by micro-computed tomography. Frontiers in Marine Science, 2:1-13. https://doi.org/10.3389/fmars.2015.00010

Beuck, L., Wisshak, M., Munnecke, A., and Freiwald, A. 2008. A giant boring in a Silurian stromatoporoid analysed by computer tomography. Acta Palaeontologica Polonica, 53:149160. https://doi.org/10.4202/app.2008.0111

Carlson, W.D., Rowe, T., Ketcham, R.A., and Colbert, M.W. 2003. Applications of high-resolution x-ray computed tomography in petrology, meteoritics and palaeontology, p. 7-22. In Mees, F., Swennen, R., Van Geet, M., and Jacobs, P. (eds.), Applications of X-Ray Computed Tomography in the Geosciences. Geological Society, London.

Conroy, G.C. and Vannier, M.W. 1984. Noninvasive three-dimensional computer imaging of matrix-filled fossil skulls by high-resolution computed tomography. Science, 80:456-458. https://doi.org/10.1126/science.226.4673.456

Donoghue, P.C.J., Bengtson, S., Dong, X., Gostling, N.J., Huldtgren, T., Cunningham, J.A., Yin, C., Yue, Z., Peng, F., and Marco, S. 2006. Synchrotron x-ray tomographic microscopy of fossil embryos. Nature, 442:680-683. https://doi.org/10.1038/nature04890

Dorador, J., Rodríguez-Tovar, F.J., and Titschack, J. 2020. Exploring computed tomography in ichnological analysis of cores from modern marine sediments. Scientific Reports, 10:201. https://doi.org/10.1038/s41598-019-57028-z

Färber, C., Titschack, J., Schönberg, C.H.L., Ehrig, K., Boos, K., Baum, D., Illerhaus, B., Asgaard, U., Bromley, R.G., Freiwald, A., and Wisshak, M. 2016. Long-term macrobioerosion in the Mediterranean Sea assessed by micro-computed tomography. Biogeosciences, 13:3461-3474. https://doi.org/10.5194/bg-13-3461-2016

Friis, E.M., Crane, P.R., Pedersen, K.R., Stampanoni, M., and Marone, F. 2015. Exceptional preservation of tiny embryos documents seed dormancy in early angiosperms. Nature, 528:551-554. https://doi.org/10.1038/nature16441

Golubić, S., Campbell, S.E., and Spaeth, C. 1983. Kunstharzausgüsse fossiler MikrobenBohrgänge. Der Präparator, 29:197-200.

Golubić, S., Friedmann, I., and Schneider, J. 1981. The lithobiontic ecological niche, with special reference to microorganisms. Journal of Sedimentary Research, 51:475-478. https://doi.org/ 10.1306/212f7cb6-2b24-11d7-8648000102c1865d

Golubić, S., Perkins, R.D., and Lukas, K.J. 1975. Boring microorganisms and microborings in carbonate substrates, p. 229-259. In Frey, R.W. (ed.), The Study of Trace Fossils. Springer, Berlin.

Görög, A., Szinger, B., Tóth, E., and Viszkok, J. 2012. Methodology of the micro-computer tomography on foraminifera. Palaeontologia Electronica, 15.1.3T:1-15. https://doi.org/ $10.26879 / 261$ palaeo-electronica.org/content/issue1-2012technical-articles/121-methodology-of-ct-onforams

Hofmann, K. 1996. Die mikro-endolithischen Spurenfossilien der borealen Oberkreide NordwestEuropas und ihre Faziesbeziehungen. Geologisches Jahrbuch, Reihe A, 136:1-151.

Kachovich, S., Sheng, J., and Aitchison, J.C. 2019. Adding a new dimension to investigations of early radiolarian evolution. Scientific Reports, 9:1-10. https://doi.org/10.1038/s41598-01942771-0

Kellner, S.K., Knappertsbusch, M.W., Costeur, L., Müller, B., and Schulz, G. 2019. Imaging the internal structure of Borelis schlumbergeri Reichel (1937): Advances by high-resolution hard x-ray microtomography. Palaeontologia Electronica, 22.1.17A:1-19. https://doi.org/10.26879/ 854

palaeo-electronica.org/content/2019/2471-borelis-micro-ct 
Kočí, T., Jäger, M., and Morel, N. 2017. Sabellid and serpulid worm tubes (Polychaeta, Canalipalpata, Sabellida) from the historical stratotype of the Cenomanian (Late Cretaceous; Le Mans region, Sarthe, France). Annales de Paléontologie, 103:45-80. https://doi.org/ 10.1016/j.annpal.2016.11.004

Kraft, P., Bruthansová, J., and Mikuláš, R. 2019. Feeding traces related to shells from the early stages of the Prague Basin, Czech Republic (Tremadocian to early Darriwilian).

Palaeogeography, Palaeoclimatology, Palaeoecology, 537:109399. https://doi.org/10.1016/ j.palaeo.2019.109399

Mays, C., Bevitt, J.J., and Stilwell, J.D. 2017. Pushing the limits of neutron tomography in palaeontology: Three-dimensional modelling of in situ resin within fossil plants. Palaeontologia Electronica, 20.3.57A:1-12. https://doi.org/10.26879/808 palaeo-electronica.org/content/2017/2066-neutron-scan-plant-resin

Parsley, R.L., Lawson, M.H., and Pojeta, J., Jr. 2018. A practical and historical perspective on the how and why of whitening fossil specimens and casts as a precursor to their photography. Fossil Imprint, 74:237-244. https://doi.org/10.2478/if-2018-0016

Pleissis, A. and Broeckhoven C. 2019. Looking deep into nature: A review of micro-computed tomography in biomimicry. Acta Biomaterialia, 85:27-40. https://doi.org/10.1016/ j.actbio.2018.12.014

Schönberg, C.H.L. and Shields, G. 2008. Micro-computed tomography for studies on Entobia: transparent substrate versus modern technology, p. 147-164. In Wisshak, M. and Tapanila, L. (eds.), Current Developments in Bioerosion. Springer, Berlin.

SkyScan, N.V. 2003. Desktop X-ray Microtomograph, Instruction Manual.

Sutton, M.D., Rahman, I.A., and Garwood, R.J. 2014. Techniques for Virtual Palaeontology. John Wiley \& Sons, New York. https://doi.org/10.1002/9781118591192

Tapanila, L. 2008. The medium is the message: imaging a complex microboring (Pyrodendrina cupra igen. n., isp. n.) from the early Paleozoic of Anticosti Island, Canada, p. 123-145. In Wisshak, M. and Tapanila, L. (eds.), Current Developments in Bioerosion. Springer, Berlin. https://doi.org/10.1007/978-3-540-77598-0_7

Tate, J.R. and Cann, C.E. 1982. High-resolution computed tomography for the comparative study of fossil and extant bone. American Journal of Physical Anthropology, 58:67-73. https:/ /doi.org/10.1002/ajpa.1330580108

Titschack, J., Baum, D., Matsuyama, K., Boos, K., Färber, C., Kahl, W.-A., Ehrig, K., Meinel, D., Soriano, C., and Stock, S.R. 2018: Ambient occlusion - A powerful algorithm to segment shell and skeletal intrapores in computed tomography data. Computers \& Geosciences, 115:7587. https://doi.org/10.1016/j.cageo.2018.03.007

Wisshak, M. 2012. Microbioerosion, p. 213-243. In Knaust, D. and Bromley, R.G. (eds.), Trace Fossils as Indicators of Sedimentary Environments: Developments in Sedimentology 64. Elsevier, Amsterdam.

Wisshak, M., Tischack, J., Kahl, W.-A., and Girod, P. 2017. Classical and new bioerosion trace fossils in Cretaceous belemnite guards characterised via micro-CT. Fossil Record, 20:173199. https://doi.org/10.5194/fr-20-173-2017 


\section{APPENDIX 1.}

Video of tube fragment of the serpulid polychaete Pyrgopolon (Pyrgopolon) deforme with Entobia boreholes and encrusting bryozoan colonies and serpulid worms, no. MHNLM EMV 2016.3.14. Video available at https://palaeo-electronica.org/content/2020/3032-micro-ct-bioerosion. Video is also available at the PE YouTube channel https://studio.youtube.com/video/TZWrKEAqDOg/edit

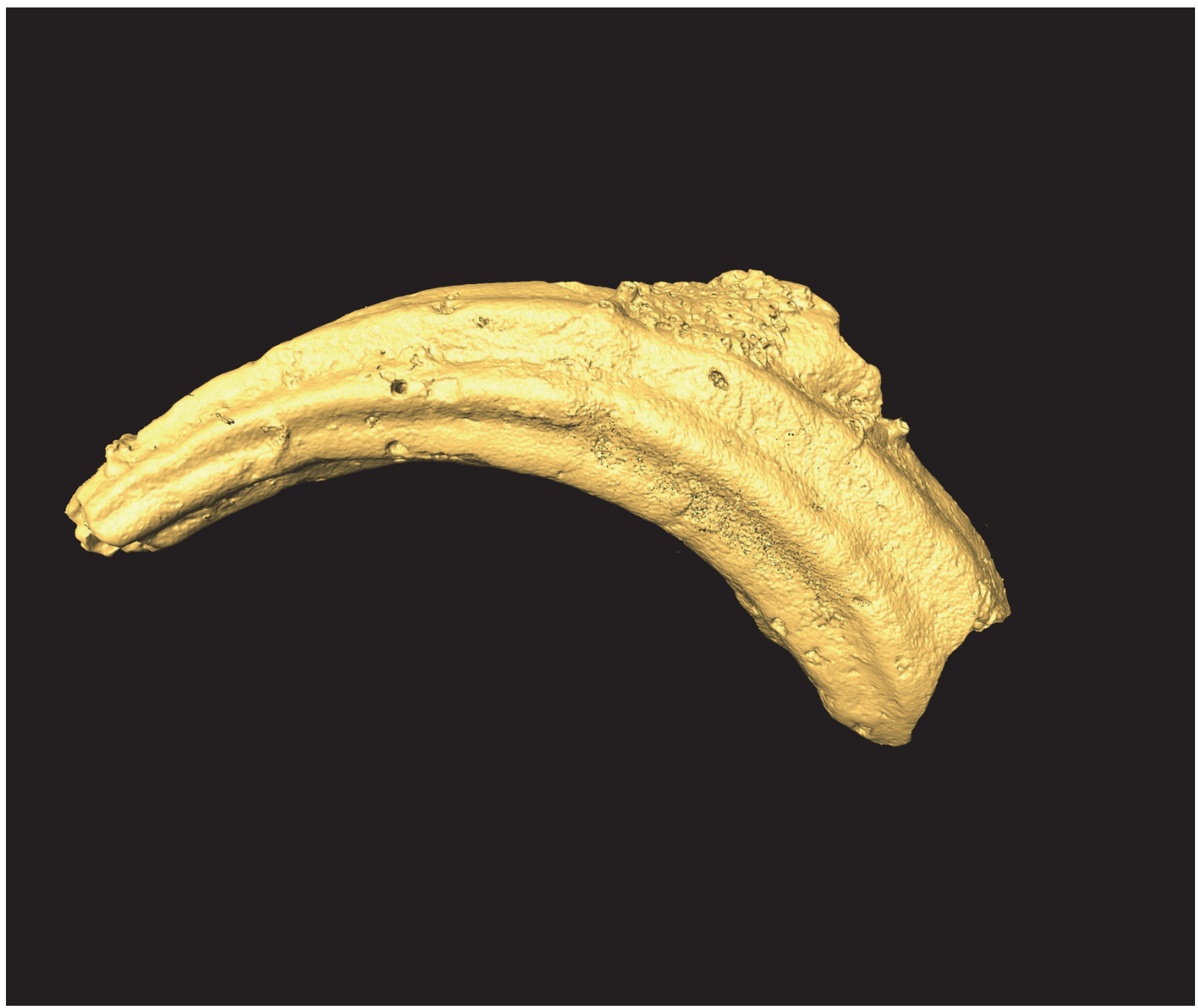

